\title{
質量スペクトル分析 \\ 土屋利 一*
}

\section{Mass Spectrometry}

Toshikazu Tsuchrya

質量スペクトルは, 分子自体および化合物の断片の質 量を示標とするスペクトルであって，光スペクトルや NMR, ESR スペクトルなどと本質的に異なる。

戦後, 質量分析法は新しい研究手段として活用され, 本法による低分子量の分子の分析，物性などに関する研 究報告は，おびただしい数に上っているが，分子量約 $200 * *$ 以上の化合物を対象とする研究は比較的少ない。 その原因は全体的にみた質量分析法力低分子量の分子に 関する基礎的研究に主力を注ぐべき段階にあったととの ほか分子量大なる化合物は固体である場合が多いために 試料の取り扱い，てのような低蒸気圧物質による装置の 污れと装置の分解能など，質量分析計に関する技術的な 点に問題があったてとである。最近質量分析法に着目し た有機化学者の要請で，てれら装置に関する諸問題が解 決され，大分子量物質の分析，構造決定などがようやく 盛んに行なわれようとしている。本稿では質量分析法と その大分子量有機化合物への応用とについて述べる。

\section{1 質量分析装置}

\section{$1 \cdot 1$ 装置の分類}

質量スペクトルを得るための装置には種類が多い。装 置のどの性質に着目するかによって，つぎのように分け ることができる。

質量分析器 イオンを直接写直乾板に印画する。 例, 元素の質量精密測定用超高分解能装置, Mattauch 型固体分析用装置など。

質量分析計 (以下 MS 子略称する) イオンを電 流として適当な方法で測定する。大多数の装置は との型である。

無線周波型 MS 磁石不用 例, 飛行時間型 MS。 イオン共振型 MS 磁石使用 例, オメガトロン。 直交磁場型 MS 磁石使用 大多数の装置はこの 型である。

二重収㪘型方向収㪘，および速度収㪘を行なう もので，分解能がよい。

単収㪘型 方向収㪘のみ, 大多数の装置はこの型 である。 $\left\{\begin{array}{l}\text { 二次収㪘 } \\ \text { 一次収㪘 }\end{array}\right.$

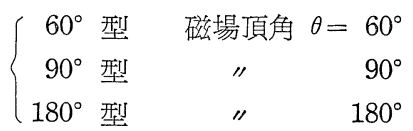

普通の装置は直交磁場，単収㪘型 MS である。以下と の型の装置について述べる。

\section{2 直交磁場型 MS}

図-1 は $60^{\circ}$ 型 MS の主要部である分析管の模型図で ある。分析管はガラスまたは金属製の管で，その両端に は各イオン源およびイオンコレクターを有し管内は常に $10^{-6} \sim 10^{-8} \mathrm{mmHg}$ の真空に排気しておく。分析管の中

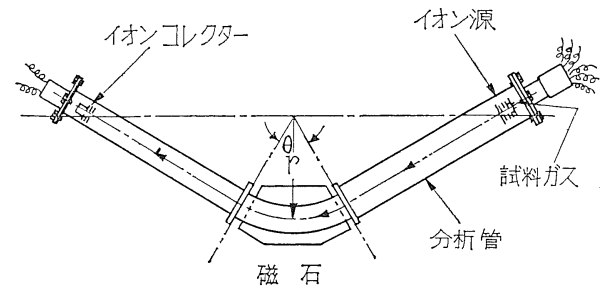

図-1 $60^{\circ}$ 形質量分析計 分析管および磁石 央の屈曲部は図のように磁石の両極の間にはさまれる。 図-1 の装置を磁極の形したがって磁場の形から扇形磁 場型 MS というととがある。分析管は図のように磁場の 扇形の緑と直角をなす。図の磁場頂角 $\theta$ は $60^{\circ}$ である。

$1.2 \cdot 1$ イオン源 イオン源の役目は試料ガス分子を イオン化し，てれを加速して分析管内にイオン線をつく

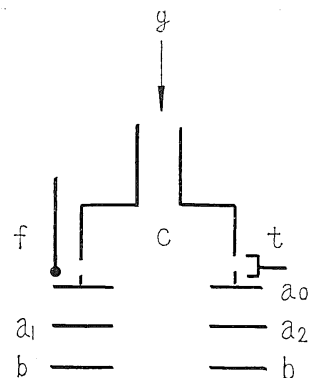

図-2 イオン源模式図 るととである。普通はガス 分子を電子衝撃してイオン 化する。図-2 はイオン源 の模式図である。モりブデ ン，タンタルあるいはステ ンレス板またはブロック製 でgから入る試料ガス分子 をフィラメント $\mathrm{f}$ から放出 される電子で衝撃してイオ ン化する。電子とガス分子 とが衝突してイオンを生ず

** 本稿においては分子量 200 500くらいまでを大分子量と いうことにする。 
るとの部分をイオン化室というととがある。ガス分子と 衝突しなかった電子はイオン化室のスリットを通り妨け て極 $\mathrm{t}$ 亿入る。 $\mathrm{a}_{1}, \mathrm{a}_{2}, \mathrm{~b}$ は極板で，スリットか沏ってあ

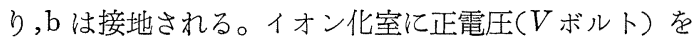
加えると, イオン化室内に生じたイオンは加速され，極 $a_{1}, a_{2}$ で集束され，b のスリットを通って分析管内にイ オン線を生ずる。

フィラメント $0.2 \phi$ 前後のタングステン線を炭化 処理゙したものを使用するてとが多い。最近はレニウム線 が賞用される。レニウム線は炭化処理する必要がない。

電子加速電圧 試料ガスをイオン化するために図-2 フィラメント $\mathrm{f}$ とイオン化室間に加える電圧 $V_{e}$ を電子 加速電圧という。普通は 70 ボルト前後である。ての程 度の電圧の電子で衝撃すると分子は分解し種々な $m / e$ のイオンを生ずる。こてで $m$ はイオンの質量数, $e$ は 電荷である。

$1 \cdot 2 \cdot 2$ イオンコレクター

図-3はイオンコレクタ 一の模式図である。 $b_{0}$ はスリットを有する極板で, 接地 してある。bはファラデー箱で直流増幅器に連結されて おり，入射するイオンを受ける。 $b_{0}$ とｂ光の間にもう 1 枚スリット極板を備えたものが多い。斜線部は $1 \cdot 2 \cdot 4$ で説明する。

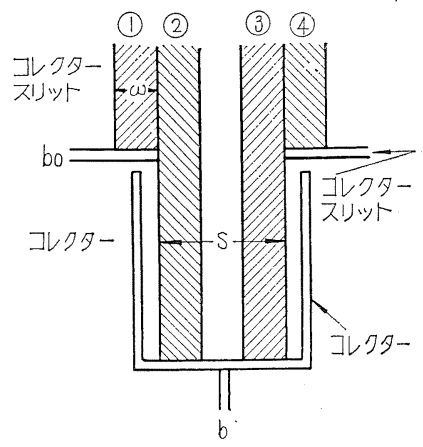

図-3 イオンコレクター模式図

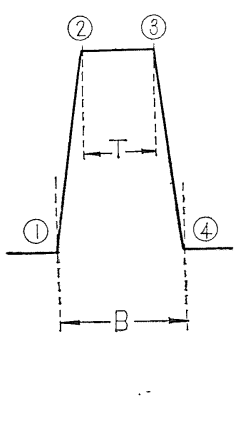

図-4 ビークの形

\subsubsection{MS の動作 （1）イオン源により，分析管} 内に $V$ ボルトに加速されたイオン線をつくり磁場内に 入射させる。とのイオン線は，種々のイオンから成る。

(2) 磁場内に入射したイオン線はフレミングの法則に従 う加速度を受け, 円軌道を 画く。軌道の曲率半径 $r$ は m/eによって異なるから最初種々のイオンを含んでいた イオン線は磁場を出るときは $m / e$ のスペクトルに分か れる。磁場強度を $H$ ガウスとすると，てれらの間には，

$$
\frac{m}{e}=5.82 \times 10^{-5} \frac{r^{2} H^{2}}{V}
$$

の関係が成立する。種々の $m / e$ のイオンの中，その軌 道半径が分析管の曲率半径 $r$ と一致するものだけが，管

*タングステン線を有機化合物（ブテンなど）の気流中で数 時間加熟すると, 線の表面にタングステンカーバイドがで きて，電子放射が安定化する。
を通過してコレクタースリットに入って増幅され，読み とられあるいは記録される。他のイオンは管壁に衝突す る。(1) 式から明らかなううにイオン軌道半径 $r$ は $H$ と $V$ との関数である。測定を行なうときは $H$ または $V$ のいずれか一方を一定とし，他方を変えてつぎつぎに異 なる $m / e$ のイオンをコレクターに入れる。 $H, V$ のいず れを变化させるかによって各測定方法を磁場走查または 電場走查という。記録紙と $V$ または $H$ を変光る回路 とを連動させておけば質量スペクトルが得られる。走査 に要する時間は装置によって異なるが，m/e 12１00 を 記録させるのに 3 15 min くらいかかる。分析管の曲率 半径は一定だから， $m / e$ 大なるイオンを記録するには磁 場 $H$ を大にするか，加速電圧 $V$ を小にするかしなけ ればならない。

1.2.4 ピーク** の形 図-11 は質量スペクトルの 例である。各ピークの高さがその $m / e$ のイオン量を示 しているはずであるが，装置の調整がうまくいっていな いと必ずしもての関係は成立しない。その場合にはての ようなスペクトルをもとにして細かい議論を行なうこと はできない。ピークの形はイオン量とピークの高さとが 比例しているかどうかのめやすとなるものであるからて れについて簡単に述べる。

コレクター部の断面を示す 図-3 亿おいて斜線の部分 は入射してきた，ある $m / e$ に相当するイオン線で, 走査 が進むにつれて左から (1),(2),(3),(4) と移動するものとす る。コレクターに入ったイオンだけが記録されるのであ るから，てのとき記録紙に画かれるピークの形は図一の ようになる。図-3,4の (1),(2)などは互いに対応する。 图-3 における位置 (2) (3) 間においてはイオン線は完全 にコレクターに入り, 図-4 の (2) (3) 間の平らな部分 T に相当する。Tの部分をピークのフラットトップとい う。スペクトルを測定する祭には各 $m / e$ のイオンの一 部だけを測ったのでは意味がない。フラットトップはイ オンの全量を実際にコレクターに受けているか不かのめ

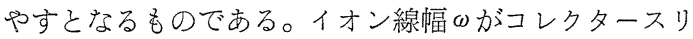
ット幅 S (図-3）と等しい場合，および走査速度が速い 場合などにはコレクターがイオン線全体を受けていても 外見上フラットトップの出ないてとがある。図-11 はフ ラットトップを出しておいて, 走查速度を上げたもので ある。

1.2 .5 分解能 磁場走查を行なう場合を考光る。 $V$ は一定であるから (1) 式から，

$$
\frac{d}{d H}\left(\frac{m}{e}\right) \infty H
$$

を得る。乙れは $H$ が大となるとともに，同じだけの磁 場変化に対してコレクタースリットを通過するスペクト ルの数が増大するととを示す。スペクトル幅は有限だか ら，m/e が大となるにつれてスペクトル線は次第に混み

** 1 本の質量スペクトル線をピークということがある。 
あってきて，ある程度以上大なる $m / e$ ではとなりあっ たスペクトルが重なって区別がつけにくくなる。ての区 別しうる極限の $m / e$ 值を分解能という。 $m / e 100$ のス ペクトルがはじめて $m / e 101$ のスペクトルと区別でき なくなったとすればその分解能 $R$ は 100 である。

となりあったスペクトルのどの程度までの重なりを区 別しうるものとして許容するかによって分解能の值はお おいに異なる。普通は相となる両ピーク間の谷間の基線 から測った高さが，ピーク高の $2 \%$ となる重なりをもっ て許容しうる限度とする。単に 2 ピークが別できさえ すればよいものとすれば分解能の值は「2\%の重なり」

の場合よりはるかに大きくなる。

分解能はある装置で扳觉る試料の分子量の上限のめや すとなるもので MS の性能を示す重要な量のひとつで ある。

図-3のようにコレクタースリット幅を $S$ ，コレクター スリット面におけるイオン線の幅を $\omega$ とすると分解能 $R$ は,

$$
R=r /(\omega+S)
$$

で表わされることがある。rは磁場半径である。装置の イオン光学的な構成が適正ならばイオン線幅 $\omega$ はイオン 源の出口スリット（図-2 bのスリット）の幅 $S_{0}$ が小な るほど小さい。したがってある装置についていえば $S$, $S_{0}$ などをできるだけせばめれば分解能はよくなる。ま た異なる装置については一般磁場半径が大なるほどよ い分解能が期待できる。分解能を無制限に上げるわけに はゆかない。まず $r$ を大にすれば大磁石を要し装置が大 型化して高価になる。また 1.2 .4 亿述べたようにある $m / e$ のイオン線全体をコレクターに受けるには $S \geqq \omega$ でなければならないが，イオン線幅 $\omega$ をイオン源出口ス リット幅 $S_{0}$ より小さくすることはできない。したがっ て $S$ を $S_{0}$ に無関係にしばることはできないし， $S_{0}$ を せまくすればイオン線は弱くなって測定できなくなるの で， $\omega, S$ をもる程度以下にしばるととはできない。

$\mathrm{C}_{30}$ くらいの有機物の研究には $m / e 500$ 前後で水素原 子 1 個すなわち $m / e 1$ の多少を確認する必要がある。 現在市販されている標準型装置の分解能は 600 前後であ るからての点では十分使用できる。

\section{2 質量スペクトルの測定, 試料の導入法}

通常の質量分析法において取り扱う陚料はガスまたは 比較的低沸点の液体であるが, $\mathrm{C}_{10} \sim \mathrm{C}_{30}$ の有機化合物は 当然固体を含むので, 試料を MS 亿送入する方法が普 通の場合と多少異なる。最も普通に測定の行なわれるガ スおよび液体試料について最初簡単に述へ, つぎに固体 試料の取り扱いを紹介する。

\section{1. ガスリーク}

図-5 は CEC 21-103C 型 MS の試料導入回路であ

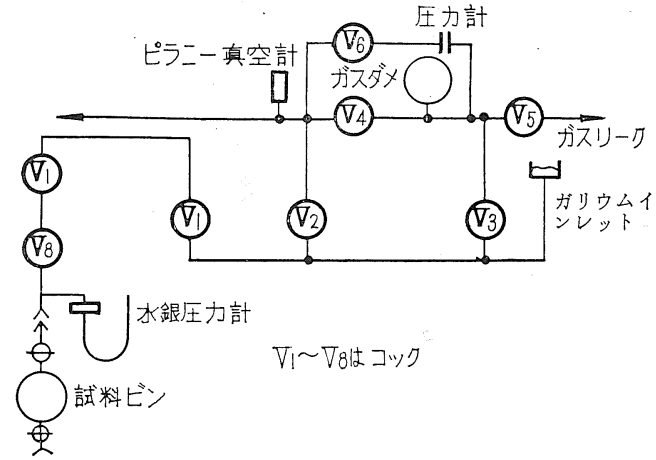

図-5 試料導入系

る。後に述べるような適当な方法で武料をガス状にして 図のガスダメにとり，ガスりークを通じてイオン源に導 入する。ガスダメの容積は約 $3 l$ で, てれに約 $5 \times 10^{-2}$ $\mathrm{mmHg}$ 程度の試料をとる。ガスリークはガラスまたは 金属八クにあけた小孔で，その直径はガスダメ中にとっ た試料ガスの平均自由行程の $1 / 30$ 以下である。とのよ うなガスリークを使用すると試料ガスは分子流としてイ オン源に流入し，イオン化室内におけるガス压および各 成分ガスの割合は，共存成分ガスの種類と量とに関係な く, 各ガスダメ中の試料ガス压に比例し，ガスダメ中の 試料成分の割合に等しくなることか知られている たがっててうして測定した值を使って，ピーク強度とガ スダメ中のガス圧との関係を示す検量線をつくるには， 1点だけを実測しててれを原点と結べばよい。

\section{$2 \cdot 2$ 気体試料の導入}

質量スペクトルを測定するために，気体試料をはかり とるのは簡単である。試料ガスを 図-5 左下方に例示し たような内容 10 100 $\mathrm{m} l$ のガラス製試料ビンにとり,ビ ンをコック $V_{8}$ の下のスリ合わせにつけて真空ポンプに よって試料回路を排気する。試料を $\mathrm{V}_{7} \sim \mathrm{V}_{8}$ 間（容積約 $3 \mathrm{ml}$ ) にとり，てれをガスダメ(約 $3 l$ ) に送り，その 圧をダイヤフラム型圧力計で正確壳読みとる。 $V_{5}$ を開 き試料をガスリークを通じてイオン源に送り，走査を開 始する。

試料中に水，アルコールなどのように四着性の物質が 含まれると再現性のよい結果が得られない。乙の場合に

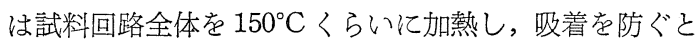
よい。

\section{$2 \cdot 3$ 液体試料の導入}

$2 \cdot 3 \cdot 1$ 図-6 a はガリウムインレットの模式図であ る。ガリウムインレットは目の細かい半融ガラスフィル タ一底を有し, 周囲にヒーターを巻いた図のような容器 にガリウム合金*を入れたもので，試料導入回路に図-5 のように接合する。図-6 b のような細管の先端を液体試 料につけると液は毛管現象で管を満たす。あらかじめ約

*約 10\% のインジウムを合む。 


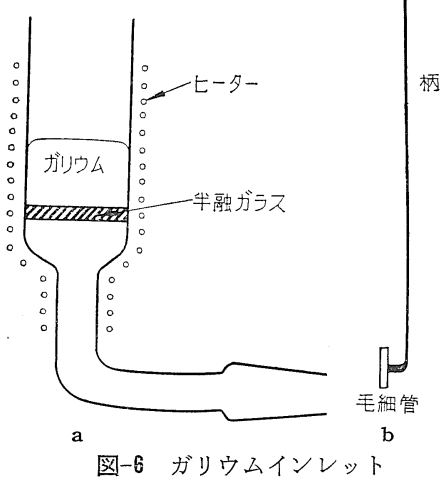

$30^{\circ} \mathrm{C}$ 亿加熱し ガリウムを溶か しておいたイン レットに, この 管をさし込み， 底のフィルター に管の一端を触 れると試料は真 空系内に吸入さ れて気化する。 ピペットとして 用いる細管とし ては注射針を適当に切断したものを用いるか，ガラス毛 細管を長いまま使用する。

$2 \cdot 3 \cdot 2$ 水銀オリフィス 図-7 のような装置である。

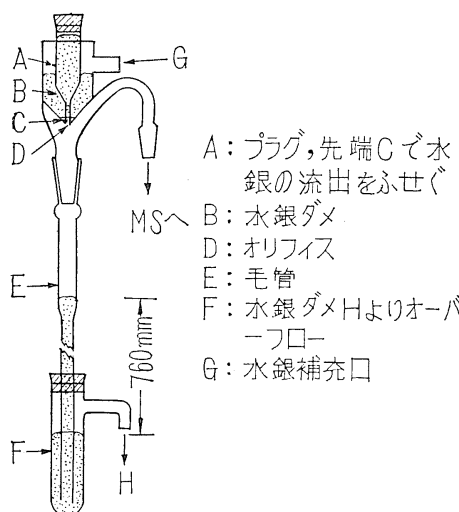

図-7 水銀オリフィス 使用するときに はオリフィス を止めてあるプ ラグをとり去り 代わりに試料を 入れた毛細管ピ ペットをオリフ ィスに触れる。 短時間で試料を 送入するととが できるが，同時 に水銀の蒸気も 入る。

$2 \cdot 3 \cdot 3$ 加熱気

化して導入する方法 場合によっては 図-5 $\mathrm{V}_{8}$ の下の スリ合わせに，一滴の試料苍入れた管をつけ，液体䇪素 で冷して排気した後，管を加熱し，気化した試料をガス ダメにとってもよい。試料が液状のまま残るような場合 には，分留が生じてガスダメ内のガスと，もとの試料と の組成が必ずしも同じでないととがある。

\section{4 固体試料の導入}

アルミナやジルコニアのようなきわめて高融点の物質 を測定するための方法もあるが，ててでは対象を有機物 に限る。

従来行なわれている方法には，イオン化室の直前に試 料をおき，てれを加熱して生ずる試料ガスのスペクトル を測定する方法と，図-5 のようなガスダメを加熱して おいて，別に加熱し，ガス化しておいた試料をてれに入 れ，あとは通常のガス試料と同様測定を行なう方法と がある。

2・4・1 イオン化室の直前で武料を気化する方法 ${ }^{2) ~ 4) ~}$ 中川はイオン源の図-2 $g$ 亿相当する管内試料容器を おき，管の外側を加熱するようにしてポリエチレンに関
する実験を行なっだ2。

この方法は比較的簡単なのか利点であるが，イオン化 室内の試料ガス圧が，炉温の小変動に敏感であるとと， 試料固体とその蒸気と力熱力学的に平衡な状態にないて と，蒸発物質によるイオン化室の污れか㵔しいとと, 試 料交換の際に分析管全体を一度常圧にしなければならぬ てとなどの欠点を有する。しかし分子か試料固体面から 離脱した直後に電子衝撃を受けて，そのままイオン化す る点は本法の特徵で, 準安定分子の検出などには適当な 方法である。

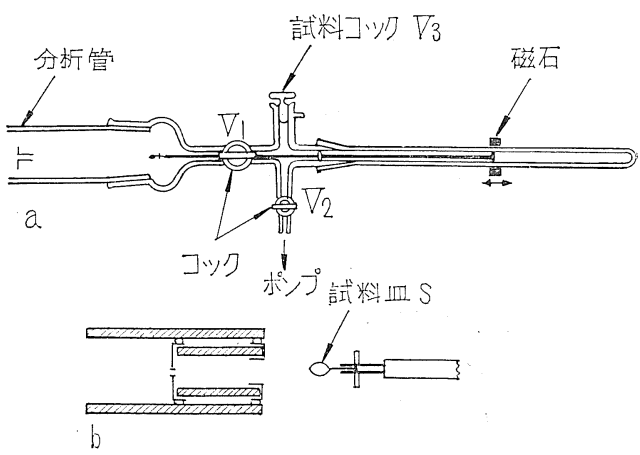

図-8 Shin らの固体試料導入系

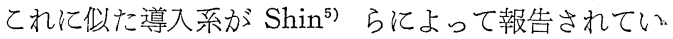
る。試料ガスは試料加熱管の小孔からイオン源に送られ. る。また試料交換の際に装置全体の真空を破る必要がな い。図-8 a は試料室の模型図である。a には図示されて いないが，左側の管内にb図の石英製炉をおく。S は棒: コック $\mathrm{V}_{1}$ の穴を自由に通り抜けるような小形スプーン でそその細い柄の先端に鉄片がついていて，外部から磁 石で左右に動かすてとができる。試料を入れるときには スプーンを右に移動しておいて $\mathrm{V}_{1}$ を閉じ,コック $\mathrm{V}_{3}$ を. 外してスプーンに試料をのせる。 $\mathrm{V}_{3}$ を閉じ $\mathrm{V}_{2}$ を通じ て排気した後 $V_{1}$ を開き，スプーンを左に動かして炻管 の中に試料を送入する。b図右側に示すようにスプーン の柄には円板が固定してあってスプーンのストッパーと. なるとともに炻室のフタとなる。

ての方式によるとグリース蒸気䎲よるスペクトルが混 入する可能性があるものと思方れる。

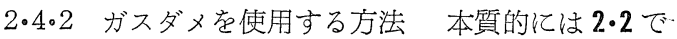
述べたガス試料導入法と同じ方法である。異なる点は固: 体試料を気化するための炉を備え，ガス状分子の凝縮を 防ぐためにガスダメや真空回路を加熱するなどの諸点で ある。後に述べるように大分子量物質のスペクトルの中 には加熱温度にきわめて敏感なものがあるので, 接触作用による影響がてれに加わらないようにガス回路，ガス ダメなどは，全部ガラス製とするのがよいと考光られて いる。

図-9 は Ryhage $\mathrm{e}^{7)}$ の加熱試料導入系の模型図である。 


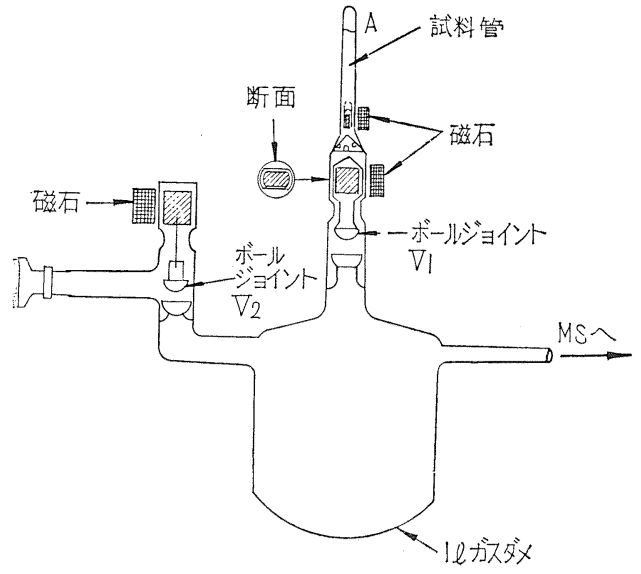

図-9 Ryhage 9 固体試料導入采

$\mathrm{V}_{1}, \mathrm{~V}_{2}$ はガラス製球状コックで，外部から磁石で開閉 する。 $V_{1}$ を閉じ， $\mathrm{A}$ を切って，乙とから $0.1 \sim 1.0$ $\mathrm{mg}$ の試料を入れた小形試験管状のガラス容器を入れる。 A 端に真空ポンプをつないで排気した後 $\mathrm{A}$ 管を開じ， $\mathrm{V}_{1}$ を開き， $\mathrm{V}_{2}$ を閉じて試料管の部分を外部から炉で加 熱し気化する。気化した陚料はガスリークを通じてイオ ン源に送られる。

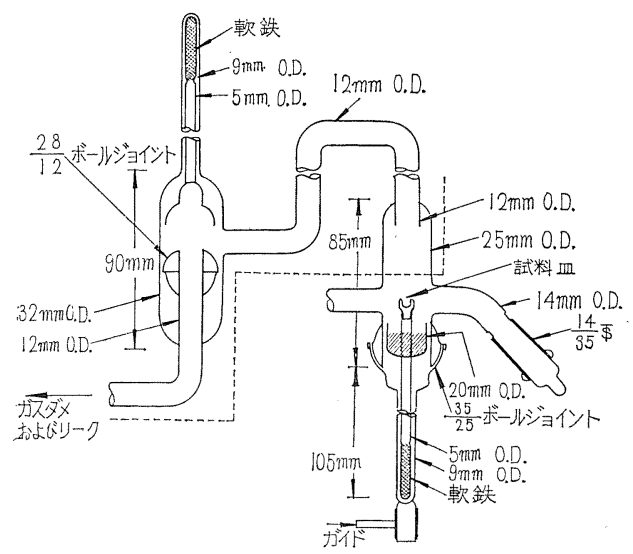

図-10 Lumpkin らの固体試料導入系

試料交換のたびごとにガラス細工をする必要のない導 入系を Lumpkin ら ${ }^{8)}$ か報告している。図-10 はその説 明図である。点線の左側の部分は恒温りウの中に入る。 右側の 35/25 ボールジョイントにはグリースを使用し， その内部のガリウムシールつきの長い柄の先端に試料サ ラをおく。柄の他端には軟鉄を封入してあって，外部か ら上下できる。まず $28 / 12$ ボールジョイントを外部から 閉じ，35/25 ボールジョイントをはずしてサラに試料を 入れ, 補助ポンプで排気した後 28/12 ボールジョイント を開いてさらによく排気する。試料サラを外部から上げ て，サラを炉の中の部分に入れると同時にガリウムシー
ルで補助ポンプを含む系と切り離す。この装置で $500^{\circ} \mathrm{C}$ までに加熱することができる。

この装置を改良したものか沛販されているとのてとで ある。

このほかにも類似の固体武料導入装置が報告され ${ }^{9)}$, 実際に使用されている ${ }^{10)}$ 。

\section{5 測定諸条件}

質量 スペクトルの様子は電子加速電圧 $V_{e}$, 電子電流 $I_{e}$ ，イオン加速電圧 $V_{i}$ ，または磁場の強さイオン源お よび試料回路温度などによって変化する。てれらのうち 最後の試料回路温度のほかは通常の装置においても電子 管回路を用いて一定に保っている。普通の測定の際の 1 例を示すとつぎのようである。 $V_{e}=70 \mathrm{eV}, I_{e}=10 \mu \mathrm{A}$, $V_{i}=400 \sim 3,000 \mathrm{~V}$ (電場走査の場合)。後に述べるよう に,特別な目的で $V_{e}$ を $10 \mathrm{eV}$ 前後に下げて測定を行な うとともある。イオン源温度は CEC 21-103C の場合

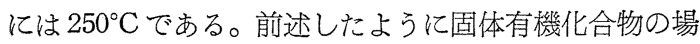
合には試料回路内で試料か熱分解するととがあるので, 再現性のよい結果を得るためには回路を全ガラス製に し，その温度の変動を最小に押さえなければならない。

このように条件を同じくれば理想的な場合にはいつ 測定しても同じ試料からは同じペクトルが得られるは ずであるが，実際には必ずしもそういかないととがある から，標準物質のスペクトルをときどき測定してスペク トルの様子をチェックする。標準物質としてはよく $n$ ブタンが使用される。

\section{3 質量スペクトル}

本節においてはスペクトルに関するごく一般的な点に ついて触れ, 大分子量有機化合物のスペクトルの特徴と 構造との関係などは 5 において述べることにする。

\section{$3 \cdot 1$ スペクトルの概観}

図-11 はC EC 21-103C 型 MS を用い，2.5 の条件で 電場走査で測定した $n$-ブタンの質量スペクトルである。

図-11 で基線が5本あるのは, 強度の著しく異なるピ ークを 1 回の測定で同じチャートで読むために，感度の 異なる 5 個の検流計を同時に振らせて記録しているため である。感度の比は下方の線から順に $1: 3: 10: 30$ : 100 となっている。

$m / e 2$ は質量数がとび離れて小さい。つぎに現われる のは質量数が 6 倍の $m / e 12$ ピークである。電場走査を 行なう場合，（1）式の $H$ を固定しておいて $V$ を変化 するのであるが，電気回路の問題があるので $V$ の可変 範囲は走査を開始するときの最小電圧を単位にしてその 約 10 倍程度の範囲である（CEC 21-103C で 400〜 4,000 V)。したがって $H$ を一定にしておいて m/e 2 か ら走査を開始すれば，一回の走査で測定しうるのは $m / e$ 20 前後までにすぎない。この不便を避けるために図-11 


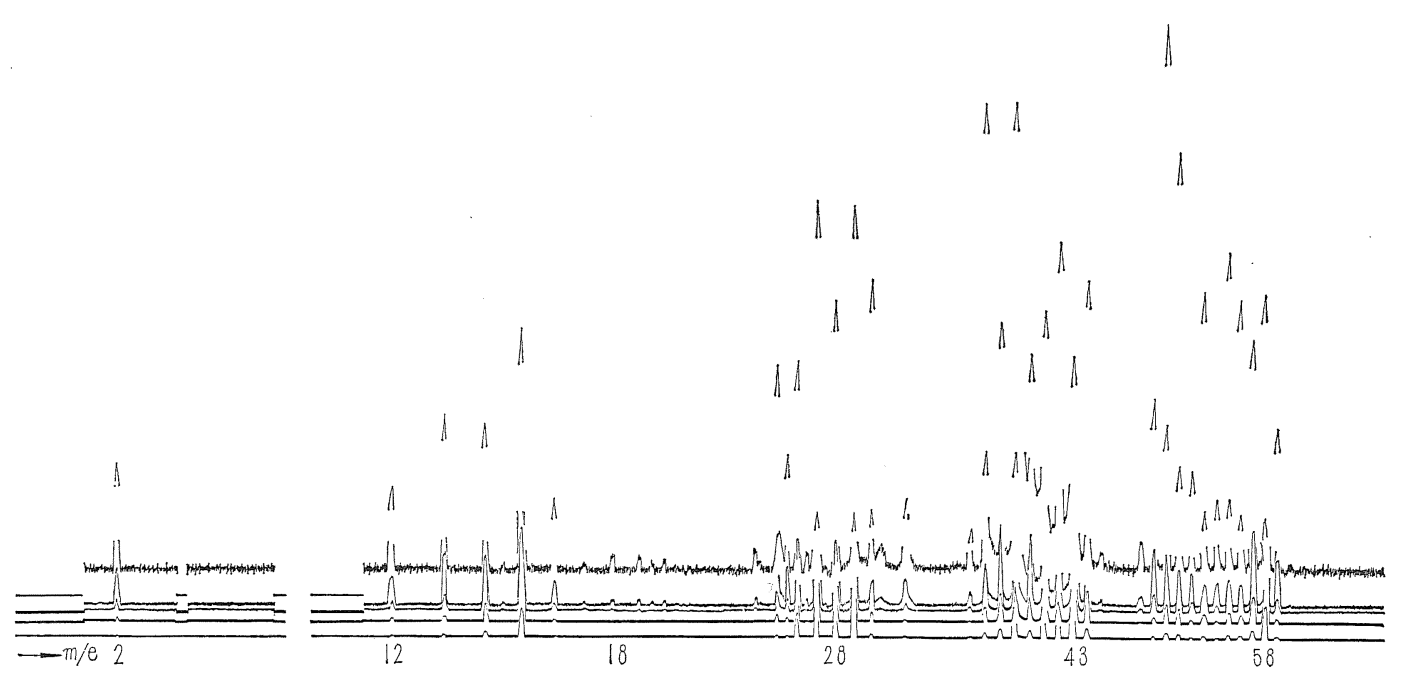

図-11 n-ブタンの質量スペクトル

の例ではある一つの $H$ 值で $m / e 2$ を走査し, つぎに さらに大なる適当な值に $H$ を固定して $m / e$ 12 120 の 範囲を走查する。さらに $m / e$ の大なる部分を測定する には改めてさらに $H$ の值を大きくする。

図-11 から，m/e 2 を別にすると，スペクトルが $m / e$ 12〜16, m/e 24〜32, m/e 36〜44 および m/e 48〜59 の 4 ピーク群から成り立っているのがわかる。各群はおの おの $\mathrm{C}_{1}, \mathrm{C}_{2}, \mathrm{C}_{3}$ および $\mathrm{C}_{4}$ を骨格とするイオンによる ピーク群である。

\section{$3 \cdot 2$ 種々のピーク}

$3 \cdot 2 \cdot 1$ 親ピーク 図-11の $m / e 58$ ピークは $n$-ブタ ン $\mathrm{C}_{4} \mathrm{H}_{10}$ がそのままイオンとなった分子イオン $\mathrm{C}_{4} \mathrm{H}_{10}{ }^{+}$ のピークで, 親ピーク (parent peak) といわれる。 m/e 59 は天然に存在する ${ }^{13} \mathrm{C}$ およ゙ $\mathrm{D}$ にって生ずるピ ークで, 同位体ピークである。 $m / e 57$ は $\mathrm{C}_{4} \mathrm{H}_{9}+$ で, 以 下H原子が 1 個ずつとれたイオンのピークが続き， m/e 48 の $\mathrm{C}_{4}+$ で $\mathrm{C}_{4}$ 群のピークが終わっている。もちろん 各ピークはその同位体ピークを伴う。たとえば親ピーク は $m / e 57 \mathrm{C}_{4} \mathrm{H}_{9}+$ の同位体イオンの寄与を含んでいる。

親ピークは必ず存在するとは限らない。一般に同族列 の化合物のスペクトルにおいて, 分子量が大となるにつ れて親分子は小となり，アルコール，アミン類などにお いてはある程度以上分子量が大となると親ピークはまっ たく消失する。どんな有機化合物でも側鎖が多いと親分 子は現われない。

$3 \cdot 2 \cdot 2$ ベースピーク 1 物質のスペクトル中の最強 ピークをベースピーク (base peak) という。n-ブタン のベースピークは m/e $43 \mathrm{C}_{3} \mathrm{H}_{7}+$ ピークである。

$3 \cdot 2 \cdot 3$ 多価イオン 2 価あるいは 3 価の電価を有す るイオンに相当するピークを生ずるてとがある。たいて いは弱いピークであるが，物質に特有な位置に現われる ことがあるので, 物質の同定に役立つととがある。図-
11 でm/e 19,19 $\frac{1}{2}, 20,25^{1} / 2,26^{1} / 2,27^{1} / 2$ などは 2 価イ オンの例である。1 洒のイオンピークと重なっているの ももちろんあるはずである。

$3 \cdot 2 \cdot 4$ 再配列イオン $n$-ブタンの $m / e 2$ の中の $\mathrm{H}_{2}{ }^{+}, m / e 16$ の中の $\mathrm{CH}_{4}{ }^{+}$などは $n$-ブタン分子がその まま電子衝撃を受けて分解するだけでは生じえない。分 解の途中で原子か洅配列して生ずるピークである。てれ らのピークは再配列ピークと呼ばれ，有機化合物のスペ クトルに普通に見られるピークである。

3.2.5 メタステーブルイオン 図-11 のほぼ $m / e$ $30 ， 32$ の位置に他のピークと形状の異なるピークがあ る。てれらはいわゆるメタステーブルイオンに基づくピ 一クであって, 最初イオン化室内に準安定な状態のイオ ンを生じ，てのイオンがイオンコレクターに向って飛行 中に分解して生ずるイオンによるものであると考光られ ている(1)。

最初イオン化室内で生じた質量 $m_{0}$ なる準安定イオン が十分加速されて磁場に入る前に質量 $m$ なるイオンと， 質量 $\left(m_{0}-m\right)$ なる中性断片とに分解し, この真の質量 $m$ なる分れたイオンが記録紙上で見掛けの質量数 $m^{*}$ の位置に記録されるものとすると，

$m^{*}=m^{2} / m_{0}$

の関係が成立する。正確な測定によると上にあげた $n$ ブタンのスペクトル中の両ピークは各 $m / e 30.4, m / e$ 31.9亿現われそれぞれ，

$$
\begin{array}{lllll}
m^{*}=30.4 & \mathrm{C}_{4} \mathrm{H}_{10} \rightarrow \mathrm{C}_{3} \mathrm{H}_{6}+\mathrm{CH}_{4} & m=58 & m_{0}=42 & \text { および } \\
m^{*}=31.9 & \mathrm{C}_{4} \mathrm{H}_{10} \rightarrow \mathrm{C}_{3} \mathrm{H}_{6}+\mathrm{CH}_{4} & m=58 & m_{0}=43
\end{array}
$$

として (2) 式によって説明されるものである。

$3 \cdot 2 \cdot 6$ バックグラウンドピーク ガスダメに試料を 入れないでスペクトルをとったとき出るピークをバック グラウンドという。普通 $m / e 17,18,28$ などに見られ， コックにグリースを使用すると $m / e 27,29,41,43,55,57$ 
などにも現われる。前に測定した試料が好けきれないで そのピークのあるものが残るてともある。図-11のm/e81, 17 はおもにバックグラウンドピークであると思われる。

\section{3 スペクトルの䒾示}

3・3・1 パタン係数 1 物質のスペクトルは上に述べ たような各種のピークから成り立っているが，測定条件 がー定ならばてれらの各ピークの相対強度も一定とな る。各ピークの相対強度を表わすためにパンタ係数を使 う。パタン係数はベースピーク強度を100としたときの 他のピークの強度である。

3.3 .2 感度 同条件で測定しても物質の種類によっ てスペクトル強度は異なる。てれを示す值が感度であ る。感度はガスダメ内の試料の単位圧力当たりのベース ピーク強度で表わされる。すなわちべースピークの高さ をガスダメ内の試料圧で割った值か感度である。感度と パタン係数を与えればある物質のスペクトルは定まる。 同装置, 同条件で測定した場合, パタン係数は安定であ るが，感度は日によって多少異なるものである。

\section{4 分 析}

質量分析法の $\mathrm{C}_{10} \sim \mathrm{C}_{30}$ 有機化合物への応用分野は分 析および構造決定の二つに大別できる。実際，䫓量分析 法による $\mathrm{C}_{10} \sim \mathrm{C}_{30}$ の有機化合物のタイプ分析によって 独特の興味ある結果か得られている。

\section{1 分析法の基礎}

適当な条件で測定を行なえばスペクトル強度対ガスダ メ内の試料圧間の関係を示す検量線が容易につくれるこ とを2・1 で述べた。また先に $n$ ーブタンの例で述べたよ うに一つの有機物の質量スペクトルは多数のピークから 成り立っている。したがってその気にさえなれば任意の m/eのピークに着目するととによって1物質に関して ピーク数だけの検量線が作れるわけである。しかし1物 質何何本ものピークか浏応するてとは，逆に特定の物質 に特有のピークというようなものか墲く，複数の成分を 合む試料のスペクトルの各ピークは各成分からの寄与を 含み，一見して試料の組成を知るというわけには加かな いととを意味する。質量分析法においても他の赤外線に よる分析法などと同様に，連立方程式を解き，その解と して分析值を得る。

いま物質 $\mathrm{a}, \mathrm{b}, \mathrm{c} \cdots$ などを各分圧 $x, y, z \cdots$ だ含む試 料の分析を行なうものとする。

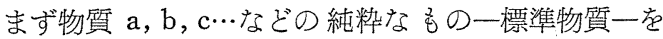
とって各スペクトルを測定し（標準スペクトルという）， おのおのについて, パタン係数および感度を計算してお く。物質 $\mathrm{a} の m / e=n$ のパタン係数 $k_{a n}$, 感度 $S_{a}$ はつ ぎのようである。

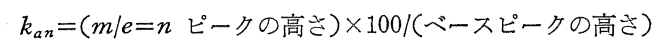

$$
\begin{aligned}
& S_{a}=(\text { ベースピーク強度)/(ガスダメにはかりとった } \\
& \text { 直後の } \mathrm{a} \text { の圧力) }
\end{aligned}
$$

つぎに分析すべき試料を圧力 $P$ だけガスダメにはか りとる。そのスペクトルを測定し，各ピークの高さを測 る。 $m / e=n$ ピークの高さ $I_{n}$ は次式で表わされる。

$$
I_{n}=\left(k_{a n} S_{a} \cdot x+k_{b n} S_{b} \cdot y+k_{c n} S_{c} \cdot z+\cdots\right) / 100 \cdots
$$

適当に成分数げけのピークを選び，おのおのについて上 のような式を立て $x, y, z \cdots$ 学末知数として解けばよい。 上に述べたてとからわかるように，オーソドックスな 定量分析法においては，(a) 試料中の成分方淀性的に既 知であるとと，(b) 各含有成分の標準物質乃㐿元にある こと，の二つが必要である。含有成分スペクトルの文献 值は参考になる程度で, 正確な分析を行なうにはぜひ自 分の装置で測定を行なわなければならない。

\section{2 有機化合物のタイプ分析}

しかしすべての試料がての (a)，(b) の両条件を満足 するとは限らない。特に液体または固体有機物は炭素数 が多く, 異性体が多数存在するのでての両条件は満たさ れるべくもなく，乙のような試料の正確な分析は不可能 である。しかし分析精度を多少犠牲にすれば，つぎのよ うな方法で化合物のタイプ分析を行なうてとができる。 ての方法は多くの化合物タイプについて行なわれている が。こてでは Brown の報告について述べる ${ }^{12) 。 ~}$

本法の基礎はつぎの実験的事実である。炭素数の多い 有機化合物のスペクトルはピーク数が多く，はなはだ複 雑であるが，一本一本のピークの代わりに適当に選んだ ピーク群の和を使用して式 (3)のようなパタン係数を作 ってみると，その様子は化合物のタイプが異なるにつれ て著しく異なる。すなわち表-1において,たとえば $\Sigma 41$ が $m / e 41,55,69,83$ ピーク強度の和を表わすものと し， $\Sigma 43 ， \Sigma 53, \cdots$ ばも表のように定義されるものと するとき，各物質のスペクトルから $\Sigma 41 / 243, \Sigma 53 / \Sigma$ $43 \cdots$ ‘どの比を作ってみると，乙れらの比は脂肪族パラ フィン, シクロパラフィン，モノオレフィン，芳香族な ぞの化合物タイプに従って著しい特徴を示すのである。

表- 2,3 亿脂肪族パラフィンとシクロパラフィンの例 をあげる。

ての両表からわかるよう亿個々の物質関して小変化 はあるが，平均的にみると両タイプの化合物の間に著し い差か存在する。そこでてれら同タイプの化合物を一括

\section{表-1}

\begin{tabular}{ll}
\hline 記号 & \multicolumn{1}{c}{ 成分ピークのm/e } \\
\hline$\sum 41$ & $41,55,69,83$ \\
$\sum 43$ & $43,57,71,85$ \\
$\sum 53$ & 53,54 \\
$\sum 67$ & $67,68,81,82,95,96$ \\
$\sum 69$ & $69,83,97$ \\
$\sum 71$ & $71,85,99$ \\
$\sum 77$ & $77,78,79,91,92,105,106,119,120,133,134$ \\
\hline
\end{tabular}


表-2 脂肪族パラフィンのスペクトル ${ }^{12)}$

\begin{tabular}{|c|c|c|c|c|c|c|}
\hline $\begin{array}{l}\text { No. of } \\
\text { Carbon } \\
\text { Atoms }\end{array}$ & Compound & $\begin{array}{l}\sum 41 / \\
\sum 43 \\
(\%)\end{array}$ & $\begin{array}{l}\Sigma 53 / \\
\Sigma 43 \\
(\%)\end{array}$ & $\begin{array}{l}\Sigma 67 / \\
\Sigma 43 \\
(\%)\end{array}$ & $\begin{array}{l}\Sigma 77 / \\
\Sigma 43 \\
(\%)\end{array}$ & $\begin{array}{l}\Sigma 69 / \\
\Sigma 71 \\
(\%)\end{array}$ \\
\hline \multirow{3}{*}{$\begin{array}{l}4 \\
4\end{array}$} & isobutane & 37.0 & - & - & - & - \\
\hline & $n$-butane & 29.0 & - & - & - & 一 \\
\hline & Av. & 33.0 & 一 & - & - & - \\
\hline \multirow{4}{*}{$\begin{array}{l}5 \\
5 \\
5\end{array}$} & isopentane & 46.5 & 1.5 & 0.22 & 0 & 3.3 \\
\hline & $\mathrm{n}$-pentane & 38.0 & 1.0 & 0.09 & 0 & 10.0 \\
\hline & neopentane & 36.7 & 1.4 & & 0 & 0 \\
\hline & Av. & 40.4 & 1.3 & 0.16 & 0 & 6.7 \\
\hline 6 & $n$-hexane & 41.5 & 1.5 & 0.10 & 0.04 & 6.6 \\
\hline 6 & 2-methylpentane & 27.5 & 1.3 & 0.16 & 0.02 & 2.0 \\
\hline 6 & 3-methylpe & 51.0 & 2.5 & 0.18 & 0.06 & 9.0 \\
\hline 6 & 2,2-dimethylbutane & 25.5 & 1.7 & 0.14 & 0.01 & 0.90 \\
\hline & 2,3-dimethylbutane & 31.8 & 1.8 & 0.25 & 0.03 & 3.5 \\
\hline & Av. & 35.5 & 1.8 & 0.17 & 0.03 & 4.4 \\
\hline 7 & $n$-heptane & 31.0 & 1.3 & 0.14 & 0.05 & 1.7 \\
\hline 7 & $2-\mathrm{m}$ & 25.0 & 1.4 & 0.17 & 0.08 & 2.4 \\
\hline 7 & 3-methylhexane & 30.0 & 1.7 & 0.24 & 0.06 & 2.1 \\
\hline 7 & 3-ethylpentane & 27.5 & 1.9 & 0.32 & 0.06 & 1.9 \\
\hline 7 & 2,2-dimethylpentane & 24.0 & 1.4 & 0.24 & 0.05 & 4.7 \\
\hline 7 & 2,3-dimethylpentane & 38.0 & 2.2 & 0.33 & 0.08 & 5.1 \\
\hline 7 & 2,4-dimethylpentane & 25.0 & 1.2 & 0.31 & 0.05 & 13.0 \\
\hline 7 & 3,3-dimethylpentane & 18.1 & 1.7 & 0.26 & 0.07 & 1.5 \\
\hline & 2,2,3-trimethylbutane & 31.0 & 1.7 & 0.43 & 0.07 & 9.5 \\
\hline & Av. & 27.7 & 1.6 & 0.27 & 0.06 & 4.7 \\
\hline 8 & $n$-octane & 24.8 & 1.3 & 0.23 & 0.08 & 2.5 \\
\hline 8 & 2-methyll & 25.3 & 1.4 & 0.34 & 0.17 & 4.7 \\
\hline 8 & hylhe & 25.5 & 1.6 & 0.33 & 0.13 & 5.3 \\
\hline 8 & ylhep & 24.2 & 1.4 & 0.37 & 0.12 & 3.0 \\
\hline 8 & $3-6$ & 22.5 & 1.7 & 0.43 & 0.14 & 6.4 \\
\hline 8 & hexane & 23.5 & 1.5 & 0.48 & 0.20 & 12.5 \\
\hline 8 & exane & 28.0 & 1.7 & 0.62 & 0.21 & 3.3 \\
\hline 8 & nethylhex & 22.7 & 1.3 & 0.43 & 0.14 & 6.8 \\
\hline 8 & exane & 23.6 & 1.4 & 0.11 & 0.05 & 3.8 \\
\hline 8 & $3,3-c$ & 18.8 & 1.4 & 0.48 & 0.12 & 4.2 \\
\hline 8 & 3,4 & 34.0 & 2.0 & 0.55 & 0.26 & 8.2 \\
\hline 8 & lpentane & 29.5 & 1.8 & 0.59 & 0.20 & 24.0 \\
\hline 8 & -trimethylpentane & 25.0 & 1.3 & 0.73 & 0.26 & 19.0 \\
\hline 8 & 2,3,3-trimethylpentane & 22.0 & 1.6 & 0.56 & 0.14 & 5.2 \\
\hline 8 & $2,3,4$-trimethylpentane & 23.0 & 1.6 & 0.52 & 0.15 & 2.5 \\
\hline 8 & $2,2,3,3-$ & 24.7 & 2.4 & 0.71 & 0.18 & 24.3 \\
\hline \multirow{3}{*}{$\begin{array}{l}8 \\
8\end{array}$} & 2-methyl-3-e & 28.9 & 1.8 & 0.63 & 0.16 & 7.7 \\
\hline & 3-methyl-3-ethylpentane & 18.5 & 1.7 & 0.48 & 0.08 & 8.5 \\
\hline & Av. & 24.7 & 1.6 & 0.48 & 0.16 & 8.4 \\
\hline 9 & $n$-nonan & 24.0 & 1.4 & 0.32 & 0.13 & 5.0 \\
\hline 9 & ylpentane & 27.0 & 2.1 & 1.0 & 0.20 & 23.0 \\
\hline 9 & exane & 25.2 & 1.7 & 0.66 & 0.06 & 14.6 \\
\hline 9 & $2,2,4-\mathrm{tr}$ & 20.0 & 1.5 & 0.46 & 0.13 & 6.0 \\
\hline 9 & 2,2, & 22.0 & 1.4 & 0.33 & 0.16 & 7.5 \\
\hline 9 & 2,3,3-trimethylhexane & 26.2 & 1.4 & 0.63 & 0.40 & 17.8 \\
\hline 9 & 3,3,4-trimethylhexane & 27.8 & 1.8 & 0.70 & 0.40 & 5.7 \\
\hline 9 & $\begin{array}{l}2,2,3,3- \\
\text { tetramethylpentane }\end{array}$ & 22.0 & .5 & 0.61 & 0.15 & 9.0 \\
\hline 9 & $\begin{array}{l}2,2,3,4- \\
\text { tetramethylpentane }\end{array}$ & 2 & 6 & 0.67 & 0.15 & 18.0 \\
\hline \multirow[t]{2}{*}{9} & $\begin{array}{l}2,3,3,4- \\
\text { tetramethylpentane }\end{array}$ & & 4 & 69 & 0.15 & 24.5 \\
\hline & Av. & 23.7 & 1.6 & 0.58 & 0.15 & 13.3 \\
\hline 10 & $n$-decane & 24.2 & 1.6 & 0.54 & 0.08 & 7.4 \\
\hline 10 & $\begin{array}{l}\text { hydrogenated triiso- } \\
\text { butylene }\end{array}$ & 24.3 & 1.0 & 0.90 & 0.19 & 30.7 \\
\hline 16 & $n$-hexadecane & 29.8 & 2.2 & 2.4 & 3.0 & 17.9 \\
\hline & & & 1.5 & 2. & 0.30 & 15.4 \\
\hline $15-17$ & $n$-paraffins & 26.9 & 1.5 & 2.6 & 0.41 & 16.1 \\
\hline
\end{tabular}

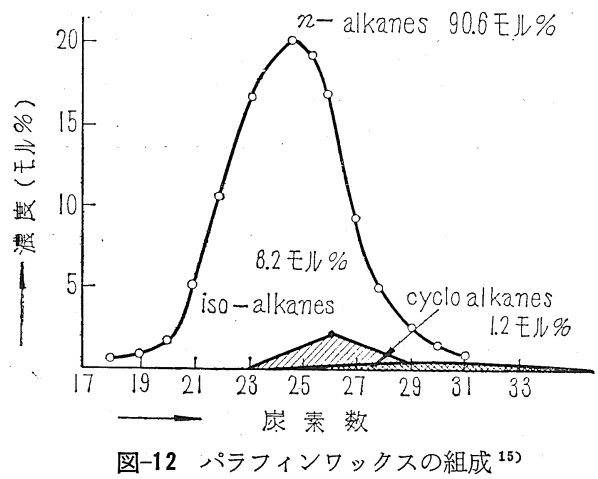

表-3 シクロパラフィンのスペクトル12)

\begin{tabular}{|c|c|c|c|c|c|c|}
\hline $\begin{array}{l}\text { No. of } \\
\text { Carbon } \\
\text { Atoms }\end{array}$ & Compound & $\begin{array}{l}\Sigma 43 / \\
\Sigma 41 \\
(\%)\end{array}$ & $\begin{array}{l}\Sigma 531 \\
\Sigma 51 \\
(\%)\end{array}$ & $\left|\begin{array}{c}\Sigma 67 / \\
\Sigma 41 \\
(\%)\end{array}\right|$ & $\begin{array}{l}\Sigma 77 / \\
\Sigma 41 \\
(\%)\end{array}$ & $\begin{array}{l}\Sigma 71 / \\
\Sigma 69 \\
(\%)\end{array}$ \\
\hline 5 & cyclopentane & 9.2 & 4.6 & 3.5 & 0 & 148 \\
\hline 6 & methylcyclopentane & 14.8 & 6.7 & 6.0 & 0.60 & 3.6 \\
\hline \multirow[t]{2}{*}{6} & cyclohexane & 18.8 & 9.5 & 4.4 & 1.1 & 17.8 \\
\hline & Av. & 16.8 & 7.0 & 5.2 & 0.90 & 10.7 \\
\hline 7 & methylcyclohexane & 5.7 & 4.9 & 12.3 & 0.70 & 4.1 \\
\hline 7 & ethylcyclopentane & 7.8 & 5.8 & 36.7 & 0.60 & 4.1 \\
\hline 7 & dimethylcyclopentane & 11.2 & 4.3 & 5.0 & 0.60 & 6.6 \\
\hline 7 & $\begin{array}{l}\text { cis-1,2- } \\
\text { dimethylcyclopentane }\end{array}$ & 15.1 & 7.7 & 4.3 & 1.1 & 15.6 \\
\hline 7 & $\begin{array}{l}\text { trans }-1,2- \\
\text { dimethylcyclopentane }\end{array}$ & 16.4 & 7.8 & 5.1 & 1.0 & 12.5 \\
\hline 7 & $\begin{array}{c}\text { cis-1,3- } \\
\text { dimethylcyclopentane }\end{array}$ & 14.4 & 6.4 & 4.8 & 0.90 & 9.9 \\
\hline \multirow[t]{2}{*}{7} & $\begin{array}{l}\text { trans }-1,3- \\
\text { dimethylcyclopentane }\end{array}$ & 15.8 & 6.6 & 5.1 & 1.1 & 12.1 \\
\hline & Av. & 12.3 & 6.2 & 10.5 & 0.90 & 9.3 \\
\hline 8 & 1,1-dimethylcyclohexane & 16.4 & 4.9 & 10.1 & 1.2 & 0.60 \\
\hline 8 & $\begin{array}{l}\text { cis-1,2- } \\
\text { dimethylcyclohexane }\end{array}$ & 12.7 & 5.6 & 10.8 & 1.1 & 3.8 \\
\hline 8 & $\begin{array}{l}\text { trans }-1,2- \\
\text { dimethylcyclohexane }\end{array}$ & 15.0 & 5.7 & 10.9 & 1.1 & 2.9 \\
\hline 8 & $\begin{array}{l}\text { cis-1,3- } \\
\text { dimethylcyclohexane }\end{array}$ & 12.9 & 4.9 & 10.3 & 1.5 & 2.5 \\
\hline 8 & $\begin{array}{l}\text { trans }-1,3- \\
\text { dimethylcyclohexane }\end{array}$ & 9.7 & 5.3 & 10.2 & 2.3 & 2.1 \\
\hline 8 & $\begin{array}{l}\text { cis-1,4- } \\
\text { dimethylcyclohexane }\end{array}$ & 11.4 & 5.9 & 12.3 & 1.4 & 1.8 \\
\hline 8 & $\begin{array}{l}\text { trans }-1,4- \\
\text { dimethylcyclohexane }\end{array}$ & 10.9 & 5.4 & 10.5 & 1.2 & 1.7 \\
\hline 8 & $\begin{array}{l}\text { 1-methyl-1-ethyl } \\
\text { cyclopentane }\end{array}$ & 5.6 & 3.6 & 16.5 & 0.80 & 3.1 \\
\hline 8 & $\begin{array}{l}\text { cis-1-methyl-2- } \\
\text { ethylcyclopentane }\end{array}$ & 12.5 & 5.5 & 13.3 & 1.1 & 6.4 \\
\hline 8 & $\begin{array}{l}\text { trans-1-methyl-2- } \\
\text { ethyl cyclopentane }\end{array}$ & 12.8 & 5.0 & 14.9 & 1.0 & 6.8 \\
\hline 8 & $\begin{array}{l}\text { cis-1-methyl-3- } \\
\text { ethylcyclopentane }\end{array}$ & 13.9 & 4.3 & 20.5 & 0.90 & 7.4 \\
\hline 8 & $\begin{array}{l}\text { trans-1-methyl-3- } \\
\text { ethylcyclopentane }\end{array}$ & 11.9 & 4.3 & 20.0 & 0.90 & 5.6 \\
\hline 8 & isopropylcyclopentane & 19.5 & 4.2 & 58.9 & 1.0 & 1.1 \\
\hline 8 & $n$-propylcyclopentane & 14.4 & 5.6 & 34.2 & 0.90 & 4.4 \\
\hline 8 & $\begin{array}{l}1,1,2- \\
\text { trimethylcyclopentane }\end{array}$ & 24.3 & 5.1 & 5.5 & 1.2 & 3.7 \\
\hline 8 & $\begin{array}{l}1,1,3- \\
\text { trimethylcyclopentane }\end{array}$ & 26.2 & 4.3 & 6.6 & 1.6 & 0.90 \\
\hline 8 & \begin{tabular}{|} 
cis, cis, cis-1,2,3- \\
trimethylcyclopentane
\end{tabular} & 20.0 & 6.4 & 3.8 & 0.80 & 49.3 \\
\hline 8 & $\begin{array}{l}\text { cis, cis, trans }-1,2,3,- \\
\text { trimethylcyclopentane }\end{array}$ & 22.4 & 5.8 & 4.0 & 1.3 & 40.5 \\
\hline 8 & $\begin{array}{l}\text { cis, trans, cis-1,2,3- } \\
\text { trimethylcyclopentnane }\end{array}$ & 24.0 & 6.1 & 4.9 & 1.3 & 22.5 \\
\hline 8 & $\begin{array}{l}\text { cis, cis, trans }-1,2,4- \\
\text { trimethylcyclopentane }\end{array}$ & 16.2 & 5.6 & 5.5 & 1.3 & 30.5 \\
\hline \multirow[t]{2}{*}{8} & $\begin{array}{l}\text { cis, trans, cis-1,2,4- } \\
\text { trimethylcyclopentane }\end{array}$ & 15.8 & 5.4 & 5.4 & 1.2 & 21.3 \\
\hline & Av. & 15.6 & 5.2 & 13.8 & 1.2 & 10.4 \\
\hline 9 & isobutylcyclopentane & 23.0 & 4.9 & 33.2 & 1.3 & 2.1 \\
\hline 9 & isopropylcyclohexane & 8.2 & 6.5 & 40.1 & 1.3 & 0.40 \\
\hline 9 & n-propylcyclohexane & 5.6 & 5.7 & 34.8 & 1.0 & 0.90 \\
\hline 9 & $\begin{array}{l}1,1,3- \\
\text { trimethylcyclohexane }\end{array}$ & 13.7 & 3.9 & 6.9 & 1.6 & 2.4 \\
\hline 10 & trans-butylcyclohexane & 94.7 & 9.8 & 34.4 & 2.5 & 6.7 \\
\hline 10 & sec-butylcyclohexane & 9.1 & 6.6 & 45.0 & 1.6 & 0.80 \\
\hline 10 & isobutylcyclohexane & 13.7 & 5.5 & 32.5 & 1.4 & 0.80 \\
\hline 10 & n-butylcyclohexane & 7.1 & 5.5 & 37.0 & 1.3 & 1.2 \\
\hline 14 & $\begin{array}{l}p \text {-di-tert- } \\
\text { butylcyclohexane }\end{array}$ & 153.0 & 6.0 & 35.2 & 4.5 & 12.4 \\
\hline
\end{tabular}


して4.1てにおける個々の化合物とみなし， $\Sigma 41, \Sigma 43$ などを4.1亿おける個々のピーク強度と考え， $\Sigma 43, \Sigma$ $71, \Sigma 41, \Sigma 69$ などの感度を使用して，先の場合とまっ たく同様にして陚料中に含まれる化合物のタイプ分析を 行なうのである。

この分析法は実際的にはなはだ有用なので，その精 度, タイプの分類法なぞが多数の研究者 ${ }^{13)}$ 22) 亿よって 検討され，ガソリンの諸留分 ${ }^{12,, 13), 16)}$, 潤滑油 ${ }^{14)}$, ワッ クス ${ }^{15)}$ ，アスファルト ${ }^{4)}$ な゙゙分析が報告されている。 図-12 はワックスの分析例である ${ }^{15}$ 。

\section{5 鹤 造 济 定}

多数の化合物の構造と質量スペクトルとの関係が研究 され，その間に相関が存在するてとが認められているが てれはほとんど経験的なもので，その相関関係を規定す る法則は現在まだ知られていない。化合物の構造とその エネルギー準位とをもとにしてスペクトルの模様を算出 しようとする理論も提出されているが231，まだてれによ ってスペクトルからもとの分子構造を推定するてとはで きない。現段階では構造の類似した多数の化合物のスペ クトルがわかっているときにだけ，ある化合物の質量ス ペクトルからその構造を推定しうるのである。

質量スペクトルと分子構造との関係は複雑で, たとえ ば分子内に，ある官能基力存在しても，スペクトルに与 えるその影響は必ずしも一定ではなく, 赤外線スペクト ルにおけるように一見して官能基の有無を推定するてと はできない。しかしスペクトルと構造との関係が複雑で あるだけに，類似化合物代関する十分な基礎データがあ れば分子構造を完全们推論しうる場合もある。構造決定 を行なうためにはまず第一にできるだけ多数の, 構造既 知の化合物のスペクトルを測定し, 分子構造との関係を 検討し整理しておく必要がある ${ }^{24)}$ 。

上述のように質量スペクトルと分子構造との関係は複 雑で，その概略をつくすととすらも困難であるが，以下 てれまでに，報告されているてとがらをいくつか紹介す る。特記しない限り, 分離された純物質の構造を考察す るものとする。

構造決定に関するまとまった文献 ${ }^{25) ~ 28) ~ か ゙ あ る 。 ~}$

\section{$5 \cdot 1$ 予備調查}

試料に関する情報は多い方がよい。特に試料化合物の 構造上の特徵, 官能基の有無および種類, 他の測定法に よって得られたデータなどに関する知識は，その質量ス ペクトルから構造を推定する際の手がかりとなる。また 試料の熱位する安定性, 蒸気圧, 純度などはスペクト ル測定の際の参考になる。

\section{2 分子量の決定}

$5 \cdot 2 \cdot 1$ 親ピークか現われる場合 親ピークの $m / e$ 值 が分子量である。使用する質量分析計の分解能は測定し
ようとする物質の分子量值より大でなければならない。

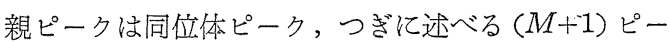
ク，不純分によるピークなどを別にして， $m / e$ が最大の ピークである。しかし最大 $m / e$ のピークが必ず親ピー クであるとは限らない。

親ピークは同系列の化合物について見れば，一般に炭 素原子数 $n$ の増加につれて減少する。ある程度以上炭素 原子数が大になると親ピークが消失するものもある。た だし直鎖脂肪酸などは例外で， $n$ の増加につれて親ピー クは最初減少するが $\mathrm{CH}_{3}\left(\mathrm{CH}_{2}\right)_{4} \cdot \mathrm{COOH}$ の親ピークの パタン係数 0.2 で極小となり, 以後 $\mathrm{C}_{9} \mathrm{H}_{19} \cdot \mathrm{COOH}$ で $9 \%, \mathrm{C}_{17} \mathrm{H}_{35}{ }^{\circ} \mathrm{COOH}$ で $67 \%$ のように，再び増大する。 てれらの酸のメチルエステル，アミドなども同様の傾问 を示す。

炭素数が等しければ安定な分子ほど親ピークは高い。 二重結合, 三重結合などを含む化合物は各対応する飽和 化合物より高い親ピークを有する。親ピークの高い順に 化合物を並べると，

アルデヒド>アルコールフニトリル>アミン

の順になる。

側鎖か増すと親ピークは減少する。またイオン化室の 温度が増すと分子の分解が助長され，親イオンは減る。

$5 \cdot 2 \cdot 2(M+1)$ ピーク $M$ を分子量とするとき， アルコール，エーテル,グリコール,アミンなどのスペク トルにおいて, 親ピークの同位体ピークに重なって $\mathrm{m} / \mathrm{e}$ $=(M+1)$ 亿試料圧の 2 乗に比例して強度を増す異常ピ 一クか現われるととがある ${ }^{29)}$ 。乙れを利用して $M$ か親 ピークであるか否かをチェックするてとができる。通常 のピークは陚料圧に比例して增減する。ての $(M+1)$ ピ 一クはイオン化室内でイオンと分子とが衝突し, 水素原 子を授受するために生ずるものと考觉られている。 $\mathrm{H}_{2}$ を試料に混ぜることによっても $(M+1)$ ピークは高くな るという。

$5 \cdot 2 \cdot 3$ 親ピークか現われない場合 上述のように， 分子量大なる化合物, 特に側鎖の多い化合物は親イオン を生じないので，質量スペクトルから直ちに分子量を見 出すととができない。

親イオンが現われない場合でも $(M+1)$ イオンか現わ

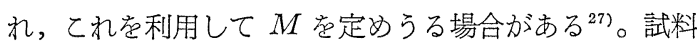
圧を変え，または試料に $\mathrm{H}_{2}$ を混じて測定したスペクト ルについて $(M+1)$ ピークの存否, 強度などを確かわ る。

試料分子は普通ガスリークを通じてイオン源に入る。 このとき分子量 $M$ なるガスの流入速度は $M^{-1 / 2}$ 亿比例 するから，ある時間内におけるガスダメの試料圧および 質量スペクトル強度の減少も $M^{-1 / 2}$ 亿比例する。ての現 象を用い，分子量既知の試料の減少量との比較によって 未知原子量を $0.5 \%$ 以内の確度で測定するてとができ 
る ${ }^{30)}$ 。 $(M+1)$ 法で求めた $M$ を，ての方法で確かめう るととがある。また試料が不純分を含有するときその スペクトルのうち，不純分に由来するものを見出せるて ともある。

そのままの形では親ピークを与えない化合物でも，乙 れを適当な誘導体に変化させることによって容易に強い 親ピークを生ずるようにするてとができる場合がある。 nードコサノールの親ピークは出ないが，そのギ酸エステ ルは親ピークを生ずる。

$5.2 \cdot 4$ 低イオン化電圧法 図-2 亿おいてfとイオ ン化室間に電子加速電圧 $V_{e}$ を加光, $V_{e}$ ボルトに加速 した電子で，試料分子を衝撃してイオンを作るのである が,生ずるイオンの量と種類とは $V_{e}$ の関数である。イオ ン量と $V_{e}$ との関係を示す曲線をイオン化効率曲線とい う。 2 原子分子 $\mathrm{XY}$ の親イオン $\mathrm{XY}^{+}$と, その断片イオ ン $\mathrm{X}+$ のイオン化効率曲線は, 一般に図-13 のような 形になる。 $V_{e}$ を下げていくと, ある電圧 $A_{2}$ 亿おいてま

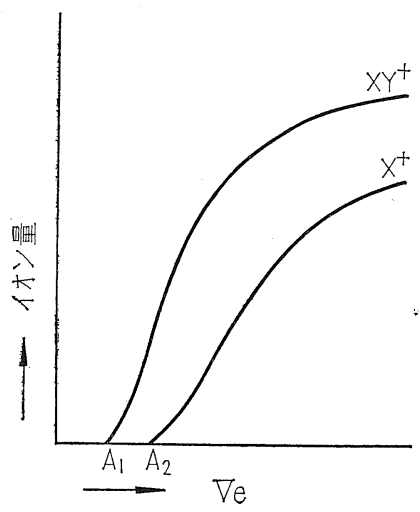

図-13 イオン化効率曲線 ず断片イオン $\mathrm{X}^{+}$が 消え;つぎに電圧 $A_{1}$ において親ピークも 消失する。 $A_{1}, A_{2}$ な どは化合物の種類お よびその断片によっ て一定值を示す。 $A_{1}$ を $\mathrm{XY}$ 分子の, $A_{2}$ を $\mathrm{XY}$ 分子の $\mathrm{X}^{+}$ イオンの, 各出現電 圧という。 $A_{1} A_{2}$ 間 の加速電圧において はスペクトルは1本 の親ピークだけとなる。多原子分子においてもとれと同 様な現象がみられる。

試料が 2 成分以上から成る場合，軽成分の親ピークは 重成分の断片ピークと区別しえないことがある。このよ うな場合に電子加速電圧を下げ，両成分の親ピークだけ か残る $V_{e}$ で測定を行なうと成分物質の分子量測定に好 都合なととがある。

親イオンの出現電圧は芳香族で $10 \mathrm{eV}$ 前後, 脂肪族 の場合はこれより高い。

$5 \cdot 2 \cdot 5$ メタステーブルピークによる方法 $2 \cdot 3$ で述 ベたメタステーブルピークによって試料の分子量を確か めうる場合がある。

フェニル $n$-ヘキシルケトンは $m / e 75.8$ にメタステ ーブルピークを生ずる。てれは式 (2) 亿おいて $m=120$, $m_{0}=190$ の場合に相当し，つぎの分解機構によるものと して説明される ${ }^{31)}$ 。れれよって分子量のみならず，化

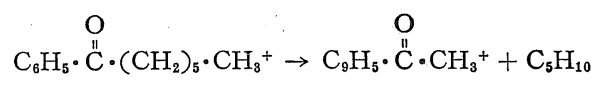

学式をもある程度確かめたてとになる。

\section{3 実験式の決定}

同位元素の寄与による $(M+1),(M+2)$ などのピー ク強度と $M$ の精密な值とが参考になる。

5・3・1 同位体ピークによる方法 天然に存在する ${ }^{13} \mathrm{C},{ }^{18} \mathrm{O}, \mathrm{D},{ }^{15} \mathrm{~N}$ などの寄与によって生ずる同位体ピー クの強度はこれらの原子の数と組み合わせとによって定 まる。 $M, M+1, M+2$ などの各ピーク強度の測定值を 各種原子の既知の天然同位体存在量から算出したピーク 強度と比較すれば実験式を求める際の参考になる。

$m / e 250$ までの $M+1, M+2$ ピーク強度と実験式と の表がある ${ }^{28)}$ 。

$5 \cdot 3 \cdot 2$ 質量の精密測定による方法 酸素原子量を 16 としたとき，他の原子量は正確にいうと整数ではな い。各元素の, 乙の質量欠損值は知られているから, $m / e$ 值を精密に測定するととができれば分子を構成する 各種原子の組み合わせ，すなわち実験式を求めうるはず であるが，高 $m / e$ 領域でてれを行なうに十分な分解能 を有する装置が現在ではまだ自由には入手できない。し かし軽い断片イオンの実験式が判明するだけでも，もと の分子構造を推定するための役に立つ。市販の装置でも $\mathrm{CO}_{2}{ }^{+}$と $\mathrm{C}_{3} \mathrm{H}_{8}{ }^{+}$とは容易に区別しうる。

つぎのような規則があり, 求めた実験式をテストする ととができる。

分子量 $M$ が偶数なる分子は窒素原子 $N$ を偶数個含み, $M$ が奇数なる分子は $\mathrm{N}$ 原子を奇数個含む。これは最も 高いピーク（すなわち同位体ピークを除く）について成 立するもので, 奇原子価を有する原子は奇質量数を有し 偶原子価を有する原子の質量数は偶数だからである。

\section{4 質量スペクトルと分子構造}

ての問題についてはかなり多くの報告があるが，本稿 においては種々の場合について詳細を述べるてとはでき ないので, 代表的な化合物のスペクトルの一般的な特徵 をあげ，文献を紹介するに止める。

5.4 .1 炭化水素 直鎖パラフィン ${ }^{32)}$ は必ず親ピー クを有し,ある炭素数の断片群中では $\mathrm{C}_{n} \mathrm{H}_{2 n+1}$ のアルキ ルイオンが最大で，その高さは $n$ の増加とともに減少す るが，親ピークは高い。図-14 は $n$-アイコサンのスペ

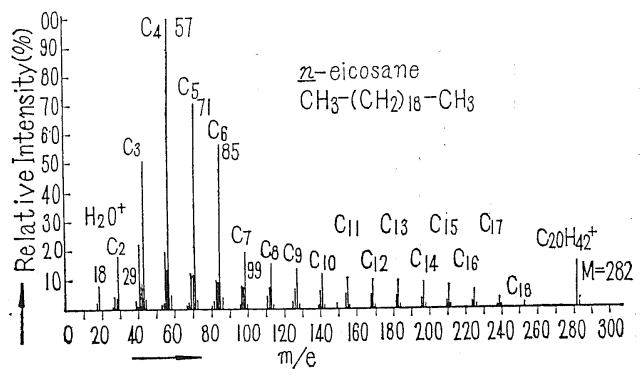

図-14 n-アイコサンの質量スペクトル $M=282$ 
クトルである ${ }^{25)}$ 。

側鎖が入るとスペクトルの様子は変わる。側鎖か短い ときは側鎖の前後，すなわち第三炭素原子の結合か切れ てできる断片イオンが多い。図-15 は 4-methyl tetratriacontane と考えられる化合物のスペクトルである。 $\mathrm{C}_{30}, \mathrm{C}_{32}$ ピークが特に高い2 ${ }^{25)}$ 。 ベンゼン核の $o, m, p$ 異性体の区別は困難である。 シクロアルカン ${ }^{33)}$ ，テルペン ${ }^{34)}$,トリテルペン ${ }^{35)}$,才 レフィン ${ }^{36)}$ ，芳香族化合物 ${ }^{37), 38) ， ホ ゚ リ フ ェ ニ ル 239) ~ な と ゙ ~}$ に関する報告がある。

5.4.2 アルコールその他 第一アルコールに関する

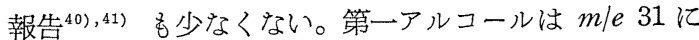
$\mathrm{CH}_{2} \mathrm{OH}^{+}$によるピークを与える。親ピークは出ないて ともある。 $(M+1)$ ピークが分子量の決定に役立つ。 $(M-2)$ 亿最大 $m / e$ ピークが出る。 $m / e$ 大なる部分に $m / e(M-18),(M-20),(M-18-20)$ などの強いピー クか現われる。スペクトルはアルコールから水 1 分子を 除いた 1-オレフィンに似たピークを含む41)。図-16 は n-hentriacontanol-1 ( $M=452)$ のスペクトルである ${ }^{25)}$ 。 第二アルコールも $m / e(M-2)$ が高い。 $-\mathrm{OH}$ を有す る炭素原子の結合か沏れて生ずる断片イオンが多いので -OH の位置は容易に推定される。図-17 はアイコサノ ル-2 のスペクトルである ${ }^{25)}$ 。 $m / e 280(=M-18), m / e$ 252 ( $=M-18-28), m / e 45$ および $m / e=(M-15)$ な どのピークが高いので - $\mathrm{OH}$ の位置がわかる。

エーテル ${ }^{29)}$, 硫化物 ${ }^{42)}, ア ミ ン{ }^{43)}$ な゙に関する報告も ある。乙れらの化合物において, 異種原子に結合する原

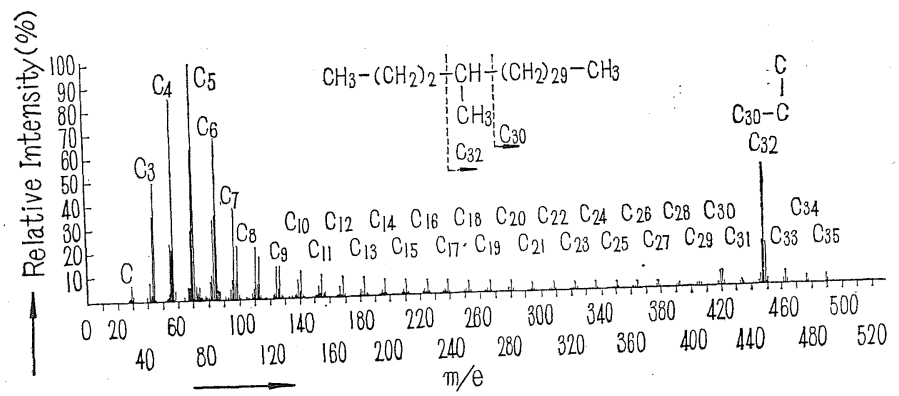

図-15 4-methyl tetratriacontane の質量スペクトル

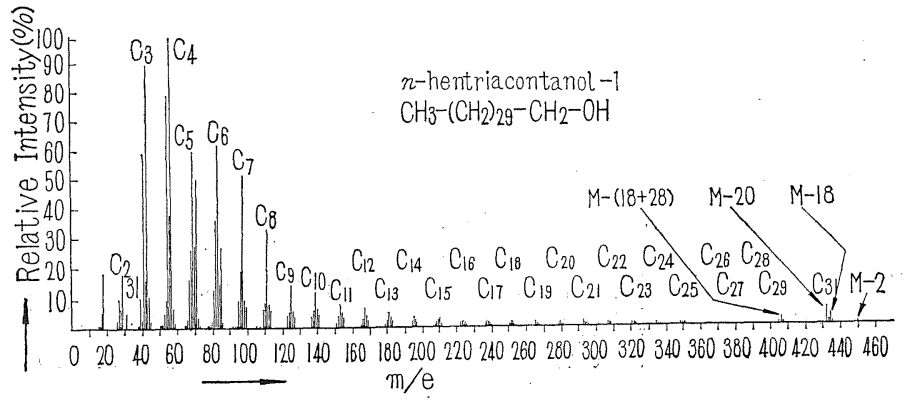

図-16 $n$-hentriacontanol-1 の質量スペクトル $M=452$

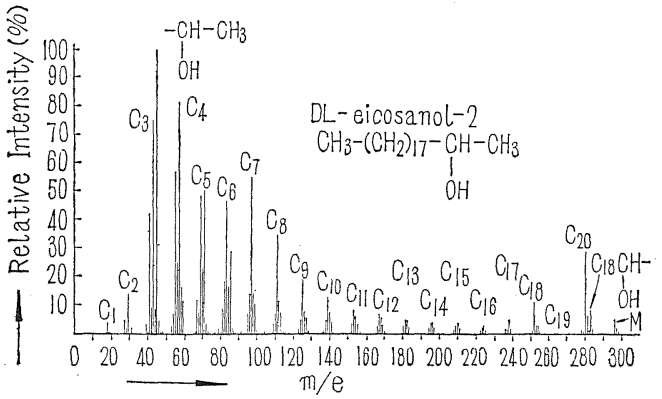

図-17 eicosanol-2 の質量スペクトル $M=298$

子団 $\mathrm{R}^{\prime}$ が $\mathrm{H}$ か $\mathrm{CH}_{3}$ ならば異種原子に対し $\beta$ 位置の 結合が， $\mathrm{R}^{\prime}$ が $\mathrm{CH}_{3}$ より大ならば $\propto$ 位置の結合が切れ やすい。

$$
\begin{aligned}
\mathrm{R}-\mathrm{CH}_{2}-\mathrm{NH}_{2} & \rightarrow \mathrm{R}+\mathrm{CH}_{2}=\mathrm{NH}_{2}{ }^{+} \\
\mathrm{R}-\mathrm{O}-\mathrm{R}^{\prime} & \rightarrow \mathrm{R}^{+}+\mathrm{OR}^{\prime}
\end{aligned}
$$

カルボニル, ニトリル, リン酸塩, 覀硫酸塩など ${ }^{27)} は$ 親ピークを生ずる。異種原子に対して $\propto$ の結合か切れや すく，異種原子を含む断片がイオンとなる。

$$
\mathrm{R}-\mathrm{CO}-\mathrm{R}^{\prime} \rightarrow \mathrm{RC} \equiv \mathrm{O}^{+}+\mathrm{R}^{\prime}
$$

長鎖カルボン酸のスペクトルはそのメチルエステルの スペクトルによく似ているし，メチルエステルはもとの 有機酸自身より蒸気圧が高いから測定しやすいので, 構 造決定には長鎖カルボン酸をメチルエステルにして測定 を行なうと都合がよい。低級脂肪酸に関する報告があ る ${ }^{44)}$ 。 $m / e 60$ に著しいピークを与えるのか封徴であ る ${ }^{45)}$ 。親ピークを生ずるとと, $m / e 31,45,59$ などに酸 素原子を含むピークを生ずるととなどでカ ルボン酸は容易にそれとわかる。

$5 \cdot 4 \cdot 3$ エステル メチルエステルに関 する報告が多い。親イオンを生ずる。図一 18 はステアリン酸メチルのスペクトルで ある25)。ベースピークは $m / e 74$ で，つぎ のように 2,3 炭素原子間で結合か沏れ，同 時に $\mathrm{H}$ 原子か再配列して生成するものと 考えられている ${ }^{31), 46) * 。 ~}$

$$
\begin{aligned}
& \mathrm{CH}_{3}-\mathrm{O}-\stackrel{1}{\stackrel{1}{\mathrm{C}}}-\stackrel{2}{\mathrm{C}} \mathrm{H}_{2}-\stackrel{8}{\mathrm{C}} \mathrm{H}_{2}-\stackrel{4}{\mathrm{C}} \mathrm{H}_{2}-\mathrm{R} \\
\rightarrow & \mathrm{CH}_{3}-\mathrm{O}-\stackrel{1}{\mathrm{C}}=\stackrel{2}{\mathrm{C}} \mathrm{H}^{+}{ }_{2}+\stackrel{3}{\mathrm{C}} \mathrm{H}_{2}=\stackrel{4}{\mathrm{C}} \mathrm{H}-\mathrm{R} \\
\stackrel{\mathrm{O}}{\mathrm{H}} &
\end{aligned}
$$

他の特徴的ピークは分子から $-\mathrm{OCH}_{3}$ の とれた $m / e=(M-31)$ ピークおよび

$$
\left[\mathrm{CH}_{3}-\mathrm{O}-\mathrm{C}-\left(\mathrm{CH}_{2}\right)_{n}{ }^{-}\right]^{+} n>1
$$

によるピークである。分子から $\left[\stackrel{2}{\mathrm{C}} \mathrm{H}_{2}-\stackrel{3}{\mathrm{C}} \mathrm{H}_{2}\right.$

\footnotetext{
* 脂肪酸から生ずる $m / e 60$ ピークも同様な機 構で生ずる ${ }^{45}$ 。
} 


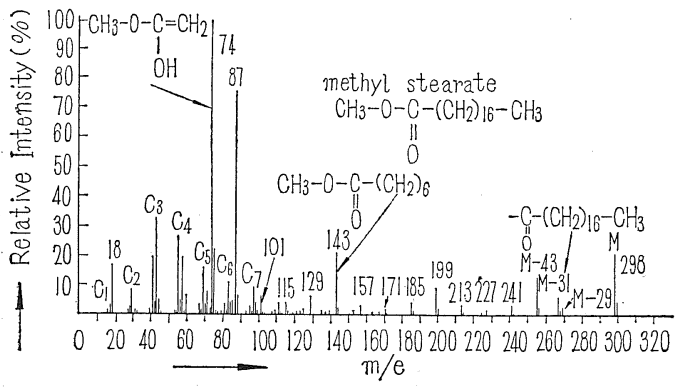

図-18 ステアリン酸メチルの質量スペクトル $M=298$

$+\mathrm{H}]$ および $\left[\stackrel{2}{\mathrm{C}} \mathrm{H}_{2}-\stackrel{3}{\mathrm{C}} \mathrm{H}_{2}-\stackrel{4}{\mathrm{C}} \mathrm{H}_{2}+\mathrm{H}\right]$ が失われたと考光 られるピークも各 $m / e=(M-29),(M-43)$ の位置に 現われる。

オレイン酸, リノール酸, リノレン酸など二重結合を 有する酸のメチルエステルも親ピークを生ずる。著しい ピークはやはり酸素原子を含む断片のピークである。

二重結合を 1 個含む $\mathrm{C}_{18}$ 酸エステルについて研究され た結果によると, シス, トランス異性や， $\alpha, \beta$ 位置以外 にある二重結合の位置による差は質量スペクトルに現わ れない。しかし Ryhage らはペトロセリン酸メチルの二 重結合を重水素で飽和させたもの(6,7-二重水素化ステ アリン酸メチル）と，ステアリン酸メチルとの両スペク トルを比較して二重結合の位置を決定した ${ }^{47)}$ 。二重結合 の存在した位置で切れたステアリン酸メチルの断片イオ ン $\mathrm{CH}_{2}-\left(\mathrm{CH}_{2}\right)_{4}-\mathrm{COOCH}_{3}+$ は $m / e 129$ に現われるのに 対し, 重水素化化合物のとれに対応する断片イオン $-\mathrm{CHD}-\left(\mathrm{CH}_{2}\right)_{4}-\mathrm{COOCH}_{3}+$ は $m / e 130$ に現われること, およびさらに炭素原子の 1 個多い $-\mathrm{CH}_{2}-\mathrm{CH}_{2}-\left(\mathrm{CH}_{2}\right)_{4}-$ $\mathrm{COOCH}_{3}{ }^{+}$は重水素化によって - CHD-CHD- $\left(\mathrm{CH}_{2}\right)_{4}-$ $\mathrm{COOCH}_{3}+$ となり質量数 2 だけ大なる位置に現われるこ となどから，6,7 炭素原子間に二重結合があるととを推

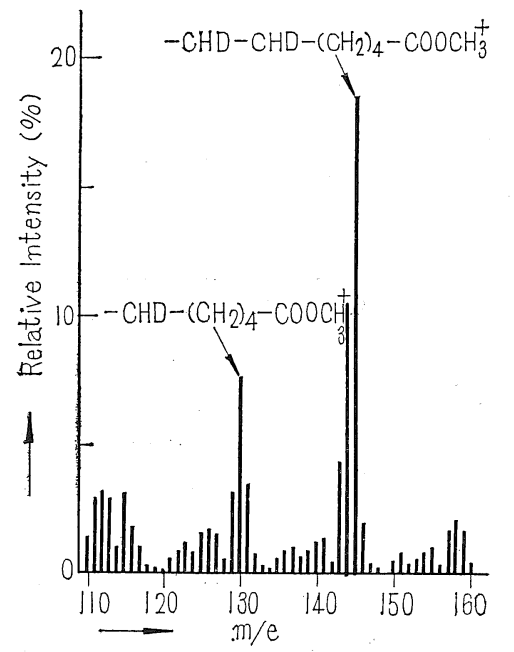

図-19 6,7-二重水素化ステアリン酸メチルの質量 スペクトルの一部
定したのである（図-19）。

同様な研究としてAnderson's mycocerosic acid の主 成分のエステル $(M=494)^{48)}$, 胆汁酸 (bile acid) メチ ル49) などの構造決定が行なわれているほか，オキソー, オキシー, メトキシ酸 ${ }^{50)}$, 不飽和脂肪酸 ${ }^{51)}$,52),53) などの メチルエステル，長鎖脂肪酸と長鎖アルコールのエステ ル ${ }^{54)}$ ，ステロイド55) 57) などに関する報告がある。

\section{(昭和 37 年 9 月 20 日受理)}

\section{文献}

1) R.E. Honig, J. Appl. Phys., 16, 646 (1945)

2) K. Nakagawa, J. Phys. Soc. Japan., 16, 741 (1961)

3) H.W. Holden, J.C. Robb. Fuel., 39, 39 (1960)

4) R. J. Clerc, M.J. O’Neal, Jr., Anal. Chem., 33, 380 (1.961)

5) H.M. Shin, H.K. Hahm, S.I. Kwon, S.H. Jo, S.B. Hong, Rev. Sci. Instr., 31, 1200 (1960)

6) R.A. Brown, W.S. Young, Nicolaides, Anal. Chem., 26, 1653 (1954)

7) R. Ryhage, Arkiv. Kemi., 16, 19 (1960)

8) H.E. Lumpkin, G.R. Taylor, Anal. Chem., 33, 476 (1961)

9) V.J. Caldecourt, ibid., 27, 1670 (1955)

10) F.W. McLafferty, ibid., 34, 2 (1962)

11) J.A. Hipple, R.E. Fox, E.U. Condon, Phys. Rev., 69, 347 (1946)

12) R.A. Brown, Anal. Chem., 23, 430 (1956)

13) H.E. Lumpkin, B.W. Thomas, A. Elliott, ibid., 24, 1389 (1952); C.E. Berry, J.K. Walker, Annual Rev. Nucl. Sci., 5, 197 (1955)

14) R.J. Clerc, A. Hood M.J. O' Neal, Anal. Chem., 27, 868 (1955)

15) M.J. O'Neal, Application of High Molecular Weight Mass Spectrometry to Oil Constitution, Paper No.2 Institute of Petl. (1953)

16) P.J. Klaas, W.P. McSweeney, Anal. Chem., 34, 30 (1962)

17) H.E. Howard. W.C. Ferguson, ibid., 33, 1870 (1961)

18) G. Franke, Erdöl u. Kohle, 13, 263 (1960).

19) G. Franke, ibid., 13, 850 (1960)

20) G. Franke, ibid., '14, 816 (1961)

21) R.A. Brown, F.W. Melpolder, W.S. Young, Petro. leum Processing, 7, 204 (1952)

22) F.W. Melpolder, R.A. Brown, W.S. Young, C.E. Headington, Ind. Eng. Chem., 44, 1142 (1952)

23) H.M. Rosenstock, A.L. Wahrhaftig, H. Eyring, Tech. Rept. No.II, June, 25, 1952. Univ of Utah, Inst. for Study of Rate Processes; H.M. Rosenstock, A.L.Wahrhaftig, H. Eyring, J. Chem. Phys., 23, 2200 (1955)

24) F.W. McLaflerty, R.S. Gohlke, Anal. Chem., 31, 1160 (1959)

25) R. Ryhage, E. Stenhagen, J. Lipid Res., 1, 361 (1960)

26) H.J. Dutton, J. Am. Oil Chemists' Soc., 38, ‘660 (1961)

27) F.W. McLaflerty, "Determination of Organic Structures by Physical Methods" Vol. II, p.93 (Edited by F.C. Nachod, W.D. Phillips, Academic Press., New York., 1961)

28) J.H. Beynon "Mass Spectrometry and its Applica- 
tions to Organic Chemistry" (Elsevier Publ. Co 1960)

29) F.W. McLafferty, Anal. Chem., 29, 1782 (1957)

30) M. Eden, B.E. Burr, A.W. Pratt, ibid., 23, 1735 (1951)

31) S. Meyerson, P.N. Rylander, J. Am. Chem. Soc., 79, 1058 (1957)

32) M.J. O’Neal, Jr., T.P. Wier, Anal, Chem., 23, 830 (1951)

33) P. Natalis, Bull. soc. roy. sci., Liege, 29, 94 (1960)

34) L. Friedman, A.P. Wolf, J. Am. Chem. Soc., 80, 2424 (1958)

35) R.I. Reed, J. Chem. Soc., 1958, 3432

36) F.W. McLafferty, Anal Chem., 31, 2072 (1959)

37) I.W. Kinney, G.L. Cook, ibid., 24, 1391 (1952)

38) S. Meyerson, Appl. Spectroscopy, 9, 120 (1955)

39) P. Bradt, F.L. Mohler, J. Research, NBS, 60, 143 (1958)

40) R.A. Brown, W.S. Young, N. Nicolaids, Anal. Chem., 26, 1653 (1954)

41) R.A. Friedel, J.L. Shultz, A.G. Sharkey, Jr., ibid., 28, 926 (1958)

42) E.J. Levy, W.H. Stahl, ibid., 33, 707 (1961)

43) J. Collin, Bull. soc. roy. sci. Liĕge., 21, 446 (1952)

44) A.G. Sharkey, Jr., J.L. Shultz, R.A. Friedel, Anal. Chem., 31, 87 (1959)

\section{本 会 記 事}

9.11：第 31 回運営委員会, 新宿中村屋, 出席者 13 名, 議事： 油化学談話会, 会誌広告の件および協会今後の運営方針 について㼟談。

9.17: 日本化学会第 5 回学協会連絡委員会, 日本化学会会議 室, 本会より麦島委員出席, 議事: 秋季研究発表大会の 件。

9.18：第 77 回油脂および油脂製品試験法部会, 東大出版会会 議窒, 出席者 15 名, 議事 : 窒素関係項目試験法の検討 そのほか。

9.20 : 第 47 回東海支部幹事会, 愛知県工業指導所, 出席者 10 名, 議事 : 油化学座談会の件。

9.20: 見学会 (東海支部), 見学先: 愛知県工業指導所。

9.20 : 油化学談話会 (東海支部), 愛知県工業指導所, 参加者 20 名, 演題之講師 : 欧米視察談 (竹本油脂) 五十嵐正 次氏。

9.25 : 界面化学部会打合わせ会, 新宿中村屋, 出席者 5 名, 議事 : 来年度ゼミナール開催地の件そのほか。
45) G.P. Happ, D.W. Stewart, J. Am. Chem. Soc., 74, 4404 (1952)

46) F.W. McLafferty, J. Appl. Spectroscopy, 11, 148 (1957)

47) N. Dinh-Nguyen, R. Ryhage, E. Stenhagen, Arkiv. Kemi., 15, 433 (1959)

48) C. Asselineau, J. Asselineau, R. Ryhage, S. StallbergStenhagen, E. Stenhagen, Acta Chem. Scand, 13, 822 (1959)

49) S. Bergstrom, R. Ryhage, E. Stenhagen, ibid., 12, 1349 (1958)

50) P.N. Rylander, S. Meyerson, H.M. Grubb, J. Am. Chem. Soc., 79, 842 (1957)

51) B. Hallgren, R. Ryhage, E. Stenhagen, Acta Chem. Scand., 13, 845 (1959)

52) J. Cason, N.K. Freeman, G. Sumrell, J. Biol. Chem., 192,415 (1951)

53) L. Ahlquist, C. Asselineau, J. Asselineau, S, Stallberg-Stenhagen, E. Stenhagen, Arkiv. Kemi., 13, 543 (1958)

54) R. Ryhage, E. Stenhagen, ibid., 14, 483 (1959)

55) R.I. Reed, J. Chem. Soc., 1958, 3432

56) S. Bergstrom, R. Ryhage, E. Stenhagen, Acta Chem. Scand., 12, 1349 (1958)

57) S.S. Friedland, G.H. Lane, Jr., R.T. Longman, M.J. O'Neal, Jr., Anal. Chem., 31, 169 (1959)

10. 2: 油化学討論会第 3 回相談会, 日本化学会会議室, 出席者 6 名。

10. 5 : 第 17 回常任編集委員会, 新宿中村屋, 出者席 9 名, 議 事: 会誌 Vol.11, No. 11,12 編集案の検討, 原稿審査 そのほか。

10. 5: 油化学討論会第 4 回相談会, 日本大学工学部会議室, 出 席者 5 名。

10. 9: 第 89 回編集委員会, 新宿中村屋, 出席者 18 名, 議事： 経過報告および来年度の編集方針について協議。

10.12：第 46 回油化学談話会 (関西支部), 大阪工業クラブ会議 室, 演題と講師 : 微生物による油脂生産 (大阪府立大学) 辰己忠次氏。

10.12: 第 65 回関西支部幹事会, 阪大工学部応化会議室, 議事： 経過報告および談話会，講習会の計画；そのほか。

新会員 $37.9 .16 \sim 10.15$

個人会員 12

飯田三男, 石井一澫, 印藤元一, 夏 惁修, 兼松 弘, 栗原 久四郎，猿谷祐康，田中基義，田中義夫，西川喜三郎，本木 松三郎, 森敕。

\begin{tabular}{|c|c|c|c|}
\hline & 編 & 集 委 & 名 \\
\hline 部 & 芳郎 & 浅原 照三 & 石井 \\
\hline 困 & 鉄郎 & 植木 憲二 & 小田 \\
\hline & 尚志 & 川村 紹雄 & 桑田 \\
\hline 森 & 三郎 & 熊野彩 從 & 桜井 \\
\hline & 太郎 & 後藤 健一 & 土屋知 \\
\hline 咅 & 言己男 & 玉井 康勝 & 野中 \\
\hline 本热 & 兵太郎 & 根本 嘉郎 & \\
\hline & 健重 & 林 静三郎 & 松原 \\
\hline & 太郎 & 福住 一雄 & 御園生 \\
\hline & 高明 & 丸茂 秀雄 & \\
\hline & 信朗 & 麦島 & 木 \\
\hline
\end{tabular}

昭和 37 年 11 月 15 日印刷 昭和 37 年 11 月 20 日発行 〔定価 250 円 送料 30 円] 編集兼発行人 川 島董 夫

印 刷 所 東京都港区赤坂溜池 5 番地

発 行 所 東京都文京区本富士町 1

社団法人日本. 油化学: 協会 振替口座東京 46463 番 '電 話 (812) (代) 2111 内線 4456 本誌広告一手取报, 㤫限大正舎

[表紙図案 赤穴宏〕
印刷人 大 沼 正吉 株式会社技報堂 東京大学工学部 5 号館内 東京都千代田区神田須田町1-10 不二会館 電話 東京 $(270) 6718$ - (291) 9545 振替替座 東 京 $14 \begin{array}{llll}4 & 6 & 0\end{array}$ 